\title{
RECENZJE
}

JOLANTA KARBOWNICZEK

Instytut Nauk o Wychowaniu

Akademia Ignatianum

Kraków
Forum Pedagogiczne

$2017 / 2$

Wpłynęło: 20.04.2017

Zatwierdzono do druku: 12.05.2017

DOI: 10.21697/fp.2017.2.24

\section{Oddziaływanie współczesnej szkoły na funkcjonowanie ucznia w przestrzeni społecznej}

[Sorokosz I., Kijowska I. M., Hurło L. (red.). (2017) Psychospołeczne wyznaczniki funkcjonowania ucznia we wspótczesnej szkole. Elbląg: Wydawnictwo Państwowej Wyższej Szkoły Zawodowej, 174 s.]

W 2017 roku mija 18 lat od momentu wprowadzenia reformy systemu edukacji w Polsce. Reforma ta była największym przedsięwzięciem modernizującym polską oświatę, związanym z występującymi w makroskali głównymi problemami społeczno-politycznymi, ekonomicznymi, technicznymi i naukowymi. Sama perspektywa jej urzeczywistnienia w XXI wieku wymagała wprowadzenia wielu zmian, które okazały się kluczowe dla polskiej oświaty, na różnych szkolnych etapach edukacyjnych. Współczesna szkoła stanęła przed niezmiernie trudnym zadaniem przygotowania ucznia do funkcjonowania w sytuacji permanentnie dokonujących się przemian otaczającej nas rzeczywistości. Zmiany są nieprzewidywalne, wynikają z przenikania się różnych nurtów, procesów i zjawisk, które mimo że zostają ze sobą w sprzeczności, oddziałują na funkcjonowanie jednostki w przestrzeni społecznej. Władze oświatowe modyfikują system edukacyjny bez dostatecznej i rzetelnej wiedzy na temat procesów zachodzących w typowej szkole. Wiele mówi się także o wartości dzieciństwa, znaczeniu edukacji, optymalizacji praktyki pedagogicznej, poszukiwaniu i tworzeniu nowatorskich rozwiązań metodycznych, ale przede wszystkim o trudnych wyzwaniach dla edukacji i wynikających z nich procesach szeroko pojętej globalizacji. Mówimy także o: trudnej szkole, trudnych uczniach, trudnych nauczycielach oraz o trudnych rodzicach. Widoczna w szkole trywializacja procesu uczenia się i nauczania - treści programowych, podręczników blokuje rzetelne zdobywanie wiedzy, umiejętności oraz kompetencji przez dziecko, niweluje jego swoiste predyspozycje, rozwijanie talentów i pasji oraz podejmowanie indywidualnych celów. Narastające problemy i trudności wychowawcze w rodzinie i szkole świadczą o ,niewydolności” w podejmowaniu konstruktywnych działań naprawczych przez rodziców i wychowawców. Rezultaty wychowania i nauczania są mierne, uczeń zdominowany negatywnymi wzmocnieniami zostaje pozbawiony 
samodzielności, niezależności. Wykazuje się reaktywnością, antypełnomocnością, stereotypowością rozwiązań bądź zupełnym brakiem ich podejmowania. Szkoła z kolei indoktrynuje wartości, normy zachowań i postaw społeczno-moralnych uczniów, instrumentalnie traktuje jednostkę, jako przedmiot wszelkich oddziaływań socjalizacyjnych. Współczesne wychowanie i nauczanie w rodzinie i szkole przyjmuje zatem charakter zniewolenia, instrukcji, podporządkowania, osaczenia, monopolizmu i manipulacji. Obecny stan wychowania i nauczania w polskich szkołach wymaga dogłębnej modyfikacji, konstruktywnych rozwiązań, zmiany przede wszystkim koncepcji wychowania oraz odejścia od zewnątrzsterowanego, typowo behawiorystycznego modelu nauczania. Ten sztywny i uniformistyczny styl pracy nauczycieli nie stwarza harmonijnych możliwości rozwojowych uczniom, wręcz odwrotnie - hamuje i niweluje je, przyczyniając się do powstawania wielu skomplikowanych problemów i trudności wychowawczych, trudności w uczeniu się i nauczaniu oraz niepowodzeń szkolnych.

W kontekście powyższych refleksji poznawczych i przemyśleń autorek powstała ciekawa dla odbiorców monografia autorstwa Lucyny Hurło, Marii Sorokosz, Iwony Marii Kijowskiej pt. Psychospołeczne wyznaczniki funkcjonowania ucznia we współczesnej szkole. Publikacja składa się z pięciu kompatybilnie i interdyscyplinarnie prezentowanych części, w których ukazano innowacyjną problematykę dotyczącą nieodpowiedniego sposobu przygotowania uczniów przez współczesną szkołę do funkcjonowania w nowym, pełnym wyzwań i trudności świecie. Autorzy monografii podjęli się niezwykle wnikliwej analizy bardzo trafnie określonych pojęć: „,edukacji na rozdrożu”, „,trudnej szkoły”, „,trudnego ucznia” oraz działań pomocowo-wspierających rozwój, edukację i zaprezentowali też, na czym polega działalność jednostki dorastającej w dobie globalizacji. W bardzo interesującym rozdziale pierwszym, zatytułowanym Edukacja na rozdrożu, Lucyna Hurło zapoznaje czytelnika z pojęciem globalizacji oraz jego wielowymiarowym znaczeniem, podkreślając szczególnie ważny aspekt edukacyjny, szanse, a także ważniejsze problemy globalizacji. W trakcie swojej refleksji koncentruje się na tzw. „innej koncepcji” wiedzy, która we współczesnym świecie rozumiana jest jako dynamiczna metamorfoza łączenia, modyfikowania oraz wykorzystywania myśli i idei. Wskazuje na jakość, strukturę oraz cechy wiedzy: nieuporządkowanie, relatywność, fragmentaryczność, powierzchowność, instrumentalizację. Według autorki obecny poziom wiedzy edukacyjnej, prezentowanej przez uczniów posiadających minimalne ambicje w jej konstruowaniu, ulega znacznemu obniżeniu. Tym samym zmniejsza się poziom wiedzy całego społeczeństwa, które powinno posiadać jej najwyższe walory. Zdaniem Lucyny Hurło, konieczne są: podniesienie jakości przekazywanej wiedzy, centralna pozycja, rewizja niewydolności poznawczej uczniów, bezrefleksyjności, konformizmu. Autorka, posługując się wysokiej jakości terminologią naukową, jasno i przejrzyście przedstawia wyzwania i zagrożenia współczesnej szkoły, która wymaga odejścia od replikowanego, inercyjnego modelu edukacji, wygaszania realizacji możliwości rozwojowych uczniów, odejścia 
od władzy nauczycieli nad uczniami, zarządzania ich tożsamością i horyzontem świata, od negacji zasobów intelektualnych i kompetencji na rzecz szkoły sprzyjającej rozwojowi ucznia. Według autorki istotne są uwarunkowania, w jakich następuje adaptacja dziecka do warunków szkolnych oraz właściwa aranżacja przestrzeni edukacyjnej. Refleksje na temat błędów popełnianych przez nauczycieli w ich pracy zawodowej oraz identyfikacje ich zachowań zamykają ten oryginalny, ciekawy i pełen refleksji rozdział.

Problematyka dotycząca ,trudnego ucznia” z perspektywy procesu uczenia się zaprezentowana została przez Irenę Sorokosz w rozdziale trzecim. Ukazanie trudności w uczeniu się w aspekcie wieloczynnikowym oddziałuje na wiele obszarów funkcjonowania ucznia w środowisku społecznym - rodzinie i szkole. Coraz więcej uczniów uczęszczających do szkoły napotyka na różnego rodzaju trudności, które uniemożliwiają im uczenie się. Szkoła jest dla nich wielkim sprawdzianem sprostania wymaganiom stawianym przez nauczycieli, którzy powinni zdawać sobie sprawę z powagi problemu, znać rodzaje trudności, ich przyczyny oraz przejawy, aby w porę i z odpowiednim skutkiem udzielić efektywnego wsparcia i pomocy. Autorka w przemyślanych podrozdziałach wskazuje na konsekwencje niepowodzeń szkolnych w nabywaniu przez uczniów klas I-III konstytutywnych umiejętności w zakresie nauki czytania, pisania, liczenia i rozumowania. Dokonuje wnikliwej charakterystyki uczniów o obniżonej sprawności intelektualnej, odnosząc się do efektywności procesu uczenia się uczniów z obniżoną inteligencją i ich psychospołecznego funkcjonowania. Specyficzne trudności w uczeniu się - dysleksja rozwojowa (jej symptomatologia, style uczenia się uczniów dyslektycznych), dysgrafia i dyskalkulia (obszary trudności matematycznych) ukazuje w precyzyjny i wartościowy poznawczo sposób. W szeroko rozbudowanym rozdziale trzecim Irena Sorokosz interesująco przedstawia lateralizację i leworęczność, zaburzenia w koncentracji uwagi oraz opisuje ucznia niedostatecznie zmotywowanego do uczenia się. Z wielkim zainteresowaniem przeczytałam tekst dotyczący indywidualnego stylu uczenia się z punktu widzenia osiąganych przez uczniów efektów edukacyjnych. Propozycje stylów nauczania i ich wielowymiarowość oraz różnorodność w celu maksymalizacji efektów pracy stanowią alternatywę do konstruktywnych, globalnych i aktywnych działań edukacyjnych podejmowanych wspólnie. Autorka poddaje swoistej i trafnej interpretacji niepowodzenia szkolne uczniów zdolnych, odwołując się do Syndromu Nieadekwatnych Osiągnięć SNO Sylwii B. Rimm, która wskazuje na bariery szkolnej kariery uczniów zdolnych. Istotę stanowi tutaj wnikliwa diagnoza, prognozowanie działań na przyszłość, wychowanie do sukcesu oraz ustalenie kierunku rozwoju, współpracy z domem rodzinnym, szkołą i środowiskiem lokalnym.

Irena Sorokosz jest również autorką rozdziału czwartego, którego tematyka odnosi się z kolei do trudności wychowawczych. „Uczeń trudny” pod względem zachowania w kontekście pejoratywności stwarza problemy w rodzinie i szkole, na co bardzo słusznie zwrócono uwagę w podjętym dyskursie. Ukazując problemowe 
i trudne zachowania uczniów, podkreślono negatywne czynniki charakteryzujące środowiska rodzinne, szkolne, grup rówieśniczych. Autorka w toku rozważań zastanawia się nad „trudnym dzieckiem”, „trudną szkołą" i „trudną klasą” w różnych destruktywnych sytuacjach. Poddaje analizie niewłaściwe zachowania uczniów w typowej trudnej klasie oraz pracę i rolę nauczyciela. W niezwykle interesujący sposób poddaje też narracji mechanizmy obronne, jako sposoby radzenia sobie z własnymi problemami. Kolejny podrozdział poświęca dziecięcemu zespołowi nadpobudliwości psychoruchowej z zaburzeniami koncentracji uwagi, dokonując jakościowej analizy zachowań uczniów. Innowacyjny wymiar stanowi według niej edukacja oparta na pedagogice oporu. Szkoła ma wykreować dziecko na jednostkę aktywną „,krytycznie”, mającą odwagę wyrażania siebie i zabierania głosu w różnych zmiennych sytuacjach. Wskazuje również autorka na typy zachowań oporowych i ich charakterystyczne formy. Absencja, wagary, odmowa chodzenia do szkoły przez dziecko w ujęciu I. Sorokosz to kolejne problemy związane z negatywną postawą uczniów wobec zajęć szkolnych, zjawisko z dziedziny patologii życia szkolnego oraz wynik nerwic, stresu, niepokoju, paniki, fobii szkolnej. Nieśmiałość i zahamowanie psychoruchowe w sferze poznawczej, emocjonalnej i ruchowej cechuje, jak podkreśla Irena Sorokosz, reaktywność społeczna, obawa przed innowacyjnymi sytuacjami, brak zaufania do ludzi, rzeczy, sytuacji, brak wiary we własne możliwości. Z kolei depresja i jej objawy stanowią, jak pisze autorka, większe ryzyko wystąpienia niepowodzeń szkolnych u dzieci, odrzucenia ich przez rówieśników, przejawiania typowych, negatywnych zachowań. W szkołach widoczna jest fala przemocy i agresji, bulling bezpośredni i pośredni („dręczenie, zastraszanie”). Są to sytuacje, których uczniowie samodzielnie nie są w stanie przezwyciężyć. Okres dorastania młodzieży, jak słusznie stwierdza Irena Sorokosz, sprzyja podejmowaniu ryzyka, przejawianiu niebezpiecznego postępowania, próbom zażywania środków psychoaktywnych, występowaniu anoreksji i bulimii. W kolejnych rozważaniach badaczka skupia się na zadaniach nauczyciela jako diagnosty, prognosty i refleksyjnego praktyka w reagowaniu na trudne zachowania i nieprzewidziane, skomplikowane sytuacje. Przedstawia przykłady skutecznych sposobów pracy z uczniem, mające na względzie jego dobro i udzielenie mu wsparcia oraz pozytywne rozwiązania. Autorka wykazała się dogłębną znajomością podjętej problematyki. Moim zdaniem zaprezentowane rozdziały jej pracy zawierają bogate, interesujące i przydatne treści, prezentujące dużą wartość poznawczą. Najważniejsze wnioski warte zapamiętania po każdym podrozdziale ujęto w ramki. Iwona Maria Kijowska w ostatnim, piątym rozdziale, zapoznaje czytelnika z tematyką działań pomocowych i wsparciem skierowanym do uczniów. Dokonuje analizy pojęć: „pomoc”, „wsparcie” oraz bezpośredniego i pośredniego charakteru relacji podmiotowej, a także typów działań. Rzetelnie omawia czynniki służące działaniom pomocowym i wsparciu, wskazując na strategie, taktyki i style pomagania. Autorka powołuje się na cenną dla psychologów i pedagogów literaturę 
specjalistyczną. Model osoby pomagającej, jej cechy i kompetencje stanowią wynik swoistych refleksji autorki.

Warto zwrócić w tym rozdziale uwagę na tak ważne cechy, wzmacniane umiejętnościami osoby pomagającej i wspierającej trudnych uczniów, a mianowicie te, które są istotne dla zrozumienia drugiej osoby, komfortu i właściwego postępowania w sytuacjach kryzysowych oraz te, które są istotne w pozytywnym działaniu. Esencję stanowi tutaj diagnoza wstępna, a w miarę potrzeby diagnoza specjalistyczna dotycząca każdego trudnego przypadku. Następnie Iwona Maria Kijowska dokonuje analizy wybranych przez siebie rodzajów pomocy, m.in.: socjoterapii, zajęć korekcyjno-kompensacyjnych w kontekście terapeutycznym, terapii logopedycznej, zajęć dydaktyczno-wyrównawczych, zajęć rozwijających uzdolnienia. Autorka w obrębie poruszanej problematyki w poszczególnych podrozdziałach sprawnie i wnikliwie dokonuje interpretacji pojęć, którymi się posługuje, dobierając w adekwatny i przemyślany sposób kategorie służące konstruowaniu świadomości ontologiczno-gnoseologicznej.

Moim zdaniem publikacja stanie się dla czytelnika cennym źródłem teoretyczno-praktycznym oraz uzupełnieniem dotychczasowych opracowań z tego zakresu tematycznego, dostępnych na polskim rynku księgarskim.

Należy nadmienić, a tym samym znacząco podkreślić, że wszystkie przytoczone w publikacji zagadnienia są klarownie opracowane i stanowią kompatybilną strukturę. Dużą wartość rzeczową ma aktualna, bogato dobrana literatura polska i obcojęzyczna. Zaletą niniejszego opracowania jest również jego zwartość i czytelność. Forma publikacji jest przemyślana, zwięzła i przejrzysta. Sam język specjalistyczny - pedagogiczny charakteryzuje się poprawnością oraz ścisłością. Dla pojęć tradycyjnych użyto również innowacyjnej - psychologicznej terminologii naukowej. Prezentowaną publikację czyta się płynnie, a myśli w niej zawarte są kompetentnie sprecyzowane przez autorki. Rzetelnie uporządkowane treści świadczą o wysokim stopniu rozumienia podjętej przez nie problematyki, a także o wysokim poziomie jej przedstawiania oraz właściwej interpretacji ogólnych i szczegółowych zjawisk, znajdujących odbicie w teorii i praktyce edukacyjnej. Teoretyczne uzasadnienie stawianych problemów jest przykładem świadomości społecznej, kompetencji kognitywno-społecznych, warsztatu pedagogiczno-psychologicznego, refleksyjności i krytyczności autorek. Publikacja wnosi nowatorskie podejście do problemu, jak również weryfikuje możliwość jego praktycznego urzeczywistnienia. Autorki precyzyjnie formułują myśli, uzasadniają własne wybory, ukazując czytelnikowi właściwe zainteresowania teoretyczno-metodologiczne. Treści zawarte w książce są bardzo przydatne dla studentów pedagogiki, nauczycieli, psychologów i innych osób zainteresowanych tematem. 